\title{
中国エネルギー需給に関する多地域一般均衡分析
}

\section{An Interregional General Equilibrium Analysis of Energy Demand/Supply in China}

\author{
宮田 譲" 渋澤 博幸** 陳 自力*** \\ By Yuzuru MIYATA, Hi royuki SHIBUSATA and Zili CHEN
}

\section{1.はじめに}

中国は， 80 年代以来，高度経済成長期に入り， 21 世紀初期まで続くと予測されている。この成長過程 に伴い, エネルギー需給が注目されるようになって きた。広大な国土面積を持つ中国にとり，地域間エ ネルギー需給はエネルギー総需給のバランスを検討 することよりも，より現実的な課題と言われている.

様々な原因により, 中国では地域間経済発展の格 差は著しく拡大している. 東南沿岸地域は 80 年代か ら急速に発展してきたが, 中部地域は緩やかであり, 西北部内陸地域は遅れている。しかし，エネルギー 資源は国内でかなり偏在し，経済発展とは逆に，主 に西北内陸地域に分布している。さらに，石炭主体 のエネルギー消費構造から, 生産地から消費地まで 膨大な量の石炭を各地域に長距離輸送しなければな らない状況にある。高度経済成長に伴い，各地域の エネルギー需要が急増するにもかかわらず，交通基 盤整備の遅れによる輸送能力不足は, 東南沿岸地域 のエネルギー需要を十分に満たすことができない恐 れもある.

その結果，各地域の経済成長にどのような影響を もたらしているのか, また，交通基盤整備の遅れに よる各地域への波及効果はどのぐらいあるのか, 数 量的に評価するため，本研究では中国を対象とする 多地域一般均衡モデルを構築し，エネルギー需給及 び地域経済へ及ぼす影響に関する多地域多部門の実 証分析を試みるものである.

キーワード：エネルギー計画, 持続的成長管理論，システム 分析, 計画手法論

* 正会員 学博 豊橋技術科学大学人文. 社会工学系

** 工博 豊橋技術科学大学人文·社会工学系

****学生会員 工修 豊橋技術科学大学博士後期課程 環境・生命工学専攻

（ ₹441 豊橋市天伯町雲雀ヶ丘 $1-1$ TEL: 0532-44-6955 FAX: 0532-44-6947 )

\section{2. 産業分類と地域分割}

本研究では，産業を表 1 の 9 産業 ${ }^{2)}$ に分類している.

表 1 産 業 分 類

\begin{tabular}{c|l}
\hline \hline 順番 & \multicolumn{1}{|c}{ 産 業 名 称 } \\
\hline 1 & 農業 \\
\hline 2 & 1次エネルギー産業 (石炭,石油開採業など) \\
\hline 3 & 基盤工業(原材料など) \\
\hline 4 & 2次エネルギー 産業 (電力,石油製品業など) \\
\hline 5 & 加工製造工業 \\
\hline 6 & 建設業 \\
\hline 7 & 運輸通信業 \\
\hline 8 & 商業 \\
\hline 9 & サービス業 \\
\hline
\end{tabular}

さらに，資源分布と経済特性によって，中国大陸 部を表 2 のような 7 地域に分割し，合わせて対外部 門も考慮して，地域間一般均衡モデルを構築する。

表 2 地域の分 割

\begin{tabular}{|c|c|}
\hline 地 域 & 地 域 内 訳 \\
\hline 1.東北地域 & 遼寧省*，吉林省*，黒竜江省* \\
\hline 2.華北地域 & $\begin{array}{l}\text { 北京市, 天津市, 河北省*, 山東省*, } \\
\text { 内蒙古区* }\end{array}$ \\
\hline 3.華東地域 & 上海市, 江蘇省, 浙江省 \\
\hline 4.華南地域 & 福建省，広東省，海南省 \\
\hline 5.華中地域 & $\begin{array}{l}\text { 山西省*, 河南省*, 安徽省*, 湖南省, } \\
\text { 湖北省, 江西省 }\end{array}$ \\
\hline 6.西北地域 & $\begin{array}{l}\text { 陜西省*, 青海省, 甘肃省，寧夏区， } \\
\text { 新疆区* }\end{array}$ \\
\hline 7.西南地域 & 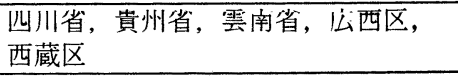 \\
\hline 8.対外部門 & 中国以外の地域 \\
\hline
\end{tabular}

基準均衡データとしては, 地域間産業連関表が必 要とされるが，現在のところ中国では地域間産業連 関表が作成されていない. 本研究では, 1992 年中国 全国の産業連関表 ${ }^{4)}$ (SNA 体系）をべースとして, 市村真一・王慧炣 ${ }^{5)}$ の中国地域間産業連関表とその 他の既存統計資料を組み合わせて, 1992 年 7 地域 9 
産業の地域間産業連関表を推計した。また，モデル に関わる外生パラメー夕（地域間の距離, 貯蓄率, 税率など）も既存統計資料 ${ }^{6}$ から推計した.

\section{3. モデルの前提条件}

（1）経済主体は一般産業, 運輸部門, 家計, 政府 とする。運輸部門に対する需要は, 生産財の需要に 伴う派生需要のみからなる.

（2）各地域で生産された個々の財は，産地によっ て差別化されているものとする.

（3）生産要素は資本と労働の 2 種類である. 労働 は地域間産業間で自由に移動でき, 資本は地域間で の移動はできないが, 産業間で自由に移動できるも のとする.

（4）市場は生産物市場（各地域各産業財の63市 場）, 生産要素市場（資本の 7 市場, 労働の 1 市場） の 71 市場とし, 各々完全競争的とする.

（5）基準年次は 1992 年とする.

\section{4. モデルの定式化}

\section{（1）一般産業の行動}

地域 s $(=1, \cdots, 7)$ における産業 $\mathrm{j}$ は, 中間投入財 $\mathrm{i}$ $(=1, \cdots, 9)$ と生産要素（資本と労働）を用い，規模に 関して収穫一定の技術を用いて財 $\mathrm{j}$ を生産するもの

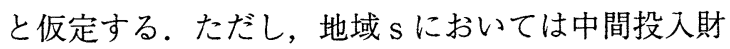

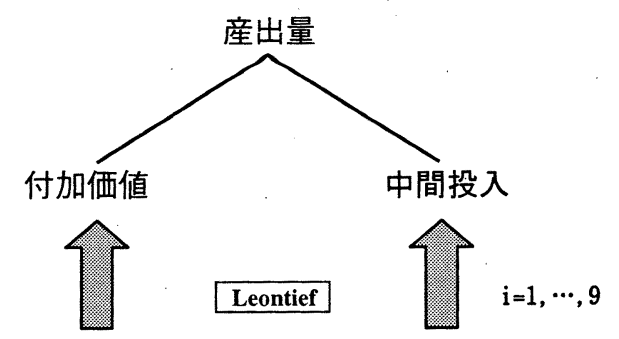

\section{資本・労働}

財 i の合成財

Cobb-Douglas

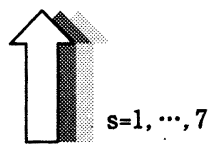

地域 $\mathrm{r}$ から財 $\mathrm{i}$ の投入

Cobb-Douglas

図 1 一般産業行動のモデル構造
もしくは最終消費財として消費される財 $\mathrm{i}$ は, 地域 $\mathrm{s}$ 内で生産されたものと, 他の地域 $\mathrm{r} て ゙$ 生産され, 運輸業者を経由して，地域内に輸送されてきたもの の 2 種類が存在し, 価格も「生産者価格」と「需要 者価格」が区別される.

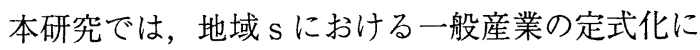
関して図 1 のように, 中間投入と生産要素投入の関 係は Leontief 型技術とする。また，資本と労㗢及び 他の地域 $\mathrm{r}$ から地域 $\mathrm{s} に$ 輸送される中間投入財に関 しては Cobb-Douglas 型技術とする。

地域 $\mathrm{s}(=1, \cdots, 7)$ 産業 $\mathrm{j}(=1, \cdots, 9)$ の生産関数は, 以下 のように表わされる。

$$
\begin{gathered}
X_{j}^{s}=\min \left\{\frac{f_{j}^{s}\left(K_{j}^{s}, L_{j}^{s}\right)}{a_{o j}^{s}}, \min _{i}\left[\frac{\chi_{i j}^{s}}{a_{i j}^{s}}\right]\right\} \\
f_{j}^{s}\left(K_{j}^{s}, L_{j}^{s}\right)=B_{j}^{s}\left(K_{j}^{s}\right)^{\alpha_{K j}^{s}}\left(L_{j}^{s}\right)^{\alpha_{L j}^{s}} \\
\left(\alpha_{K j}^{s}+\alpha_{L j}^{s}=1\right)
\end{gathered}
$$

$$
\chi_{i j}^{s}=A_{i j}^{s} \prod_{r}^{7}\left(x_{i j}^{r s}\right)^{\alpha_{i j}^{r s}}, \quad\left(\sum_{r}^{8} \alpha_{i j}^{r s}=1\right)
$$

ここで, $X_{j}^{s}$ : 地域 $\mathrm{s}$ 産業 $\mathrm{j}$ の産出量

$\chi_{i j}^{s}$ : 地域 $\mathrm{s}$ 産業 $\mathrm{j}$ の中間合成財 $\mathrm{i}$ の投入量 $x_{i j}^{r s}$ : 地域 $\mathrm{s}$ 産業 $\mathrm{j}$ における地域 $\mathrm{r}$ 財 $\mathrm{i}$ の中 間投入量

$K_{j}^{s}$ : 地域 $\mathrm{s}$ 産業 $\mathrm{j}$ の資本投入量 $L_{j}^{s}$ : 地域 $\mathrm{s}$ 産業 $\mathrm{j}$ の労働投入量 $a_{o j}^{s}$ : 地域 $\mathrm{s}$ 産業 $\mathrm{j}$ の付加㑋值率 $a_{i j}^{s}$ : 地域 $\mathrm{s}$ 産業 $\mathrm{j}$ の中間投入係数 $A_{i j}^{s}, B_{j}^{s}, \alpha_{i j}^{r s}, \alpha_{K j}^{s}, \alpha_{L j}^{s}$ : 地域 $\mathrm{s}$ 産業 $\mathrm{j}$ の技術 パラメータ

地域 $\mathrm{s}$ 産業 $\mathrm{j}$ の利潤は, 次のように表わされる.

$$
\begin{aligned}
\pi_{j}^{s}=p_{j}^{s} X_{j}^{s} & -\sum_{i}^{9} \sum_{r}^{7} q_{i}^{r s} x_{i j}^{r s} \\
& -\left(1+\tau_{j}^{s}\right)\left(\rho^{s} K_{j}^{s}+\omega L_{j}^{s}\right)
\end{aligned}
$$

ここで, $p_{j}^{s}$ : 地域 $\mathrm{s}$ の財 $\mathrm{j}$ の生産者価格 $q_{i}^{r s}$ : 地域 $\mathrm{r}$ の財 $\mathrm{i}$ に対する地域 $\mathrm{s}$ での需 要者価格 
$\tau_{j}^{s}$ : 地域 $\mathrm{s}$ の産業 $\mathrm{j}$ の純間接税率

$\rho^{s}$ : 地域 $\mathrm{s}$ の資本収益率

$\omega:$ 賃金率

産業の利潤最大化問題から, 地域 $\mathrm{s}$ 産業 $\mathrm{j}$ の生産 量 $X_{j}^{s}$ に伴う資本と労働及び各地域の $\mathrm{i}$ 財に対する 派生需要関数が得られる.

$$
\begin{aligned}
& K_{j}^{s}=\left(\frac{\alpha_{k j}^{s} \omega}{\alpha_{L j}^{s} \rho^{s}}\right)^{\alpha_{L j}^{s}} \frac{a_{o j}^{s} X_{j}^{s}}{B_{j}^{s}} \\
& L_{j}^{s}=\left(\frac{\alpha_{L j}^{s} \rho^{s}}{\alpha_{K j}^{s} \omega}\right)^{\alpha_{k j}^{s}} \frac{a_{o j}^{s} X_{j}^{s}}{B_{j}^{s}} \\
& x_{i j}^{r s}=\frac{p_{j}^{s} \alpha_{i j}^{r s} \chi_{i j}^{s}}{q_{i}^{r s} a_{i j}^{s}}
\end{aligned}
$$

前提条件(1)により, 運輸部門は他の財の需要に伴 う輸送需要に見合うだけの運輸サービスを提供する と仮定されるため, 以上の式では， $i \neq 7$ とする.

\section{(2) 家計の行動}

本研究では、家計は全国において集計化された一 つの家計として考え，与えられた所得のもとで効用 最大化を図る。

家計効用は各地域の財 i についての Cobb-Douglas 合成財について, Cobb-Douglas 型効用関数として定 式化し, 効用最大化問題は以下のように記述される.

$$
\begin{aligned}
\operatorname{Max} U & =\prod_{i}^{9}\left(c h_{i}\right)^{\beta_{i h}}, \quad\left(\sum_{i}^{9} \beta_{i h}=1\right) \\
c h_{i} & \equiv \prod_{r}^{7}\left(c h_{i}^{r}\right)^{\beta_{i h}^{r}} \quad\left(\sum_{r}^{7} \beta_{i h}^{r}=1\right)
\end{aligned}
$$

S.t. $\quad \sum_{i}^{9} \sum_{r}^{7} q_{i}^{r h} c h_{i}^{r}=y_{h}, \quad(\mathrm{i} \neq 7)$

\section{ここで, $c h_{i}$ : 合成財 $\mathrm{i}$ の消費量}

$c h_{i}^{r}$ : 地域 $\mathrm{r}$ の財 $\mathrm{i}$ に対する消費量

$q_{i}^{r h}$ : 地域 $\mathrm{r}$ の財 $\mathrm{i}$ に対する消費者価格

$y_{h}:$ 家計の貯蓄控除後の可処分所得

式(8)〜(10)による効用最大化の問題から, 地域 $r$

財 $\mathrm{i}$ に対する需要関数は次式で表わされる.

$$
c h_{i}^{r}=\frac{\beta_{i h} \beta_{i h}^{r} y_{h}}{q_{i}^{r h}}
$$

ここで, $\beta_{i h}, \beta_{i h}^{r}:$ 分配パラメー夕

家計が所有する労働と資本を国内に供給した場合 に得られる貨金所得と資本所得, 及び政府からの移 転所得が家計所得総額になる。家計所得総額は以下 のように表わされる.

$$
\begin{aligned}
H=\sum_{s}^{7} H^{s} & =\sum_{s}^{7}\left[\rho^{s}\left(1-\eta^{s}\right) K^{s}\right]+\omega L \\
& +\operatorname{TrGH}
\end{aligned}
$$

\section{$\eta^{s}$ : 地域 $\mathrm{s}$ 資本の固定資産減耗率}

$\mathrm{TrGH}$ ：政府から家計への移転所得

賃金所得，資本所得をタックスベースとした政府 の直接税率を $\tau_{D}$ とすると, 家計可処分所得 $Y_{h}$ は次 式になる。

$$
Y_{h}=\left(1-\tau_{D}\right)(H-\mathrm{TrGH})+\mathrm{TrGH}
$$

家計の貯蓄率を $\sigma$ とすると, 家計が消費可能な所 得は次式で表される.

$$
y_{h}=(1-\sigma) Y_{h}
$$

\section{（3）政府の行動}

本研究では, 一つの政府を仮定する. 政府は各地 域からの直接税と純間接税の税収を政府収入とし, 一定の政府消費支出率と移転率のもとで政府消費と 家計への所得移転を行い, 収入と支出との差は政府 貯蓄になる，政府の行動は次のように記述される。

$$
\begin{gathered}
\frac{\tau_{D}}{1-\tau_{D}}\left(Y_{h}-\operatorname{TrGH}\right)+\left(\sum_{s}^{7}\left[\rho^{s}\left(1-\eta^{s}\right) K^{s}\right]+\omega L\right) \tau_{j}^{s} \\
=y_{g}+S G \\
\text { ここで, } \quad y_{g} \text { : 政府消費支出額 } \\
S G \text { : 政府貯蓄額 }
\end{gathered}
$$

政府消費は Cobb-Douglas 合成財の形で行い, 政府 消費支出の地域 $\mathrm{r}$ 財 $\mathrm{i}$ に対する需要関数は次式のよ うである。 


$$
c g_{i}^{r}=\frac{\beta_{i g} \beta_{i g}^{r} y_{g}}{q_{i}^{r g}}, \quad(\mathrm{i} \neq 7)
$$

$$
\text { ここで, } \beta_{i g}, \beta_{i g}^{r} \text { : 政府消費の分配パラメータ }
$$

\section{（4）投資支出}

本研究では, 家計, 政府, 対外部門の貯蓄, 固定 資産減耗が投資総額を決定する，そのバランス式は 次のように示される。

$$
p_{I} I=\sigma Y_{h}+S G+S O+\sum_{s}^{7} \sum_{j}^{9} D_{j}^{s}
$$

ここで， $p_{I}$ : 投資財価格

\section{$I ：$ 実質投資}

$D_{j}^{s}$ : 地域 $\mathrm{s}$ 産業 $\mathrm{j}$ の固定資本減耗額

実質投資 $I$ は，投資の技術的構成を Leontief 夕イ プとして ${ }^{1)}$ ，以下のように設定する.

$$
\begin{gathered}
I=\min _{i}\left\{\frac{c I_{1}}{b_{1}}, \cdots, \frac{c I_{9}}{b_{9}}\right\}, \quad(\mathrm{i} \neq 7) \\
c I_{i}=\prod_{r}^{7}\left(c I_{i}^{r}\right)^{\beta_{i I}^{r}}, \quad \sum_{r}^{7} \beta_{i I}^{r}=1
\end{gathered}
$$

ここで, $c I_{i}: I$ に伴う財 $\mathrm{i} の$ 合成財 $c I_{i}^{r}: c I_{i}$ に伴う地域 $\mathrm{r}$ 財 $\mathrm{i}$ への需要 $b_{i}, \beta_{i l}^{r}:$ 技術パラメータ

そして, I に伴う生産財の需要は投資費用最小化 のもとで，以下のように表わされる.

$$
\begin{gathered}
c I_{i}=b_{i} I \\
c I_{i}^{r}=\frac{\beta_{i I}^{r} p_{i I} b_{i} I}{q_{i}^{r I}}
\end{gathered}
$$

ここで, $p_{i I}$ : 投資合成財 $\mathrm{i}$ の価格

\section{（5）運輸部門の行動}

運輸部門に対する需要は, 地域間及び地域内の生 産財の移動に伴う派生需要である.

輸送費用は発送地の運輸部門に支払われるものと 仮定し, 地域 $\mathrm{r}$ 運輸部門に対する輸送サービスの総 需要量は次式のように表われる.

$$
\begin{aligned}
T^{r} & =\sum_{j}^{9} \sum_{s}^{7} x_{7 j}^{r s}+c h_{7}^{r}+c g_{7}^{r}+c I_{7}^{r}+e_{7}^{r}-m_{7}^{r} \\
& =\sum_{i, j}^{9} \sum_{s}^{7} x_{i j}^{r s} d^{r s} \theta_{i}^{r}+\sum_{i}^{9}\left(c h_{i}^{r} d^{r h}+c g_{i}^{r} d^{r g}\right. \\
& \left.+c I_{i}^{r} d^{r I}+e_{i}^{r} d^{r 8}-m_{i}^{r} d^{8 r}\right) \theta_{i}^{r} \quad(\mathrm{i} \neq 7)
\end{aligned}
$$

上式で， $x_{7 j}^{r s}$ は地域 $\mathrm{r}$ の財 $\mathrm{i}$ を地域 $\mathrm{s}$ の産業 $\mathrm{j}$ に供 給する量 $x_{i j}^{r s}$ に応じた輸送サービス量を表わす。

$c h_{i}^{r}, c g_{i}^{r}, c I_{i}^{r}, e_{i}^{r}, m_{i}^{r}$ は, それぞれ地域 $\mathrm{r}$ 財 $\mathrm{i}$ に対する家計，政府消費，投資支出及び輸出，輸入 の最終需要量である.

前提条件(2)より，地域別の財を全て差別化してい るため, 異なる財に対する単位あたりの輸送サービ ス量も違うので, 本研究では, $\theta_{i}^{r}$ を地域 $\mathrm{r}$ 財 $\mathrm{i}$ を共 通的輸送単位に変換するパラメータとして導入する。 表 3 で示される $\theta_{i}^{r}$ の值は, 1992 年中国地域間産業連 関表の中間投入部分をクロスセクションデータとし て，最小二乗法によって求めたものである.

表 3 地域別財別の $\theta_{i}^{r}$ 值 $\left(\times 10^{-2}\right)$

\begin{tabular}{c|c|c|c|c|c|c|c}
\hline \hline & 地域 1 & 地域 2 & 地域 3 & 地域 4 & 地域 5 & 地域 6 & 地域 7 \\
\hline 産業 1 & 0.003 & 0.002 & 0.002 & 0.002 & 0.002 & 0.002 & 0.002 \\
\hline 産業 2 & 0.055 & 0.040 & 0.107 & 0.039 & 0.040 & 0.039 & 0.040 \\
\hline 產業 3 & 0.001 & 0.001 & 0.001 & 0.003 & 0.003 & 0.003 & 0.003 \\
\hline 産業 4 & 0.020 & 0.035 & 0.013 & 0.026 & 0.027 & 0.027 & 0.027 \\
\hline 産業 5 & 0.016 & 0.015 & 0.010 & 0.015 & 0.015 & 0.015 & 0.015 \\
\hline 産業 6 & 0 & 0 & 0 & 0 & 0 & 0 & 0 \\
\hline 産業 7 & - & - & - & - & - & - & - \\
\hline 産業 8 & 0.016 & 0.017 & 0.138 & 0.001 & 0.005 & 0.003 & 0.005 \\
\hline 產業 9 & 0.006 & 0.005 & 0.077 & 0.004 & 0.004 & 0.004 & 0.004 \\
\hline
\end{tabular}

$d^{r s}$ は地域 $\mathrm{r}$ 中心都市から地域 $\mathrm{s}$ 中心都市までの距 離であり, $d^{r r}$ は地域 $\mathrm{r}$ 中心都市から, 地域内の各省, 自治区省会都市までの平均距離を表わす，中国では 地域間の長距離輸送は，ほとんど鉄道運輸となるの で，ここでの距離は鉄道線路の距離が用いられてい $3^{7)}$.

また, $d^{r h}, d^{r g}, d^{r l}$ は地域 $\mathrm{r}$ から全国に対して家 計，政府消費及び投資支出の財を供給する平均距離 を表わす． $d^{r h}\left(d^{r g}, d^{r I}\right.$ も同様である）は，次の ように計算される。 


$$
d^{r h}=\sum_{i}^{9} c h_{i}^{r} \theta_{i}^{r} / c h_{7}^{r}, \quad(\mathrm{i} \neq 7)
$$

$c h_{7}^{r}$ は, 地域 $\mathrm{r}$ から家計への財供給量 $\Sigma_{i} c h_{i}^{r}$ に対 応する輸送サービスの派生需要量である.

運輸部門の生産関数は他の産業と同じタイプの技 術を用いるとすれば, 式(20)に示す総需要を満たす ための費用最小化問題は次式のようである.

$$
\operatorname{Min} \sum_{i}^{9} \sum_{r}^{7} q_{i}^{r s} x_{i 7}^{r s}+\left(1+\tau_{7}^{s}\right)\left(\rho^{s} K_{7}^{s}+\omega L_{7}^{s}\right)
$$

$$
\text { S.t. } \quad X_{7}^{s}=T^{s}, \quad(\mathrm{i} \neq 7)
$$

以上の最適化問題から, 地域 $\mathrm{s}$ の運輸部門の資本 と労働及び財 $\mathrm{i}$ に対する派生需要関数は次のように 導かれる。

$$
\begin{aligned}
& K_{7}^{s}=\left(\frac{\alpha_{k 7}^{s} \omega}{\alpha_{L 7}^{s} \rho^{s}}\right)^{\alpha_{L 7}^{s}} \frac{a_{07}^{s} X_{7}^{s}}{B_{7}^{s}} \\
& L_{7}^{s}=\left(\frac{\alpha_{L 7}^{s} \rho^{s}}{\alpha_{K 7}^{s} \omega}\right)^{\alpha_{K 7}^{s}} \frac{a_{07}^{s} X_{7}^{s}}{B_{7}^{s}} \\
& x_{i 7}^{r s}=\frac{p_{7}^{s} \alpha_{i 7}^{r s} \chi_{i 7}^{s}}{q_{i}^{r s} a_{i 7}^{s}}
\end{aligned}
$$

\section{（6）財価格}

産業のゼロ利潤条件から, 以下の価格方程式が導 かれ, 各地域で生産された財の価格が求められる.

$$
\begin{aligned}
& p_{j}^{s}= \sum_{i}^{9} \sum_{r}^{7} p_{j}^{r} a_{i j}^{r s}+\sum_{i}^{9} \sum_{r}^{7} p_{j}^{r} a_{i j}^{r s} \theta_{i}^{r} d^{r s} \\
&+\left(1+\tau_{j}^{s}\right)\left(\omega l_{j}^{s}+\rho^{s} k_{j}^{s}\right) \quad(i \neq 7) \\
& P= {\left[\mathrm{I}-A^{T}(p)\right]^{-1}\left(1+\tau_{j}^{s}\right)\left(\omega l_{j}^{s}+\rho^{s} k_{j}^{s}\right) } \\
& こ こ て ゙, \quad P \text { : 財生産者価格べクトル } \\
& l_{j}^{s}, \quad k_{j}^{s} \text { : 単位産出に伴う生産要素の投入 } \\
& A^{T}(p): \text { 投入係数の転置行列. }
\end{aligned}
$$$$
\text { ただし, } A^{T}(p) \text { で運輸部門価格 } p_{j}^{s} \text { に係わる要素 }
$$
は， $\sum_{i} \theta_{i}^{r} a_{i j}^{r s} d^{r s}$ である. $A^{T}(p)$ は中間投入につ いて, 地域間代替が許されているため, 価格体系に
依存して変化する.

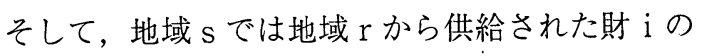
需要者価格は次のように求められる.

中間投入財 : $q_{i}^{r s}=p_{i}^{r}+p_{7}^{r} \theta_{i}^{r} d^{r s}$

最終消費財 $: \quad q_{i}^{r h}=p_{i}^{r}+p_{7}^{r} \theta_{i}^{r} d^{r h}$

$$
\begin{aligned}
& q_{i}^{r g}=p_{i}^{r}+p_{7}^{r} \theta_{i}^{r} d^{r g} \\
& q_{i}^{r I}=p_{i}^{r}+p_{7}^{r} \theta_{i}^{r} d^{r l}
\end{aligned}
$$

\section{（7）対外部門}

対外部門の役割は, 中国の輸入を所得とし, 中国 の輸出財を購入する。輸入所得と輸出支出との差額 は貯蓄されるものとする。輸出と輸入は次式のよう に設定する。

$$
\begin{aligned}
& e_{i}^{r}=e_{i}^{r^{*}}\left(q_{i}^{r 8^{*}} / q_{i}^{r 8}\right) \\
& m_{i}^{r}=m_{i}^{r^{*}}\left(X_{i}^{r} / X_{i}^{r^{*}}\right)
\end{aligned}
$$

ここで, $e_{i}^{r^{*}}, m_{i}^{r^{*}}, q_{i}^{r 8^{*}}, X_{i}^{r^{*}}$ : 基準年次の輸出量, 輸入量, 価格, 産出量

また，対外部門の収支制約式は次のように表わさ れる。

$$
\sum_{r}^{7} \sum_{i}^{9}\left(q_{i}^{8 r} m_{i}^{r}-q_{i}^{r 8} e_{i}^{r}\right)=S O
$$

ここで, $e_{i}^{r}$ : 地域 $\mathrm{r}$ による財 $\mathrm{i}$ の輸出量

$m_{i}^{r}$ : 地域 $\mathrm{r}$ の財 $\mathrm{i}$ に対する輸入量

$S O$ : 対外部門の貯蓄

$q_{i}^{8 r}$ は地域 $\mathrm{r}$ 輸入財 $\mathrm{i}$ の需要者価格であり, 財 $\mathrm{i} の$ 輸入価格(c.i.f) $p_{i}^{e}$ に港からの輸送費 $p_{7}^{8} d^{8 r} \theta_{i}^{e}$ を加え るものである。本研究では, 輸入財を国産財と差別 化しないため, $q_{i}^{8 r}=q_{i}^{r r}$ とし, 輸入財の輸送費用は 外国に支払われるものと仮定する。

また, $q_{i}^{r 8}=p_{i}^{r}+p_{7}^{r} d^{r 8} \theta_{i}^{r}$ は, 対外部門における 地域 $\mathrm{r}$ の財 $\mathrm{i}$ の需要者価格に他ならない.

$d^{r 8}$ は, 基準年次のデータを用い, 次の式によっ て求められる. 


$$
d^{r 8}=\sum_{i}^{9} e_{i}^{r} \theta_{i}^{r} / e_{7}^{r}, \quad(\mathrm{i} \neq 7)
$$

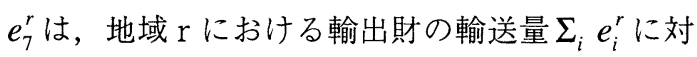
応する輸送サービスの派生需要量である.

\section{5. 均衡条件式}

生産物市場と生産要素市場に関する均衡条件は, 一般化価格ベクトル $\mu\left(p_{i}^{r}, \rho^{r}, \omega\right)$ を用いて, 次式 のように記述される。

\section{（1）財市場}

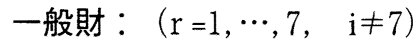

$$
\begin{aligned}
& X_{i}^{r}(\mu)+m_{i}^{r}(\mu)=\sum_{s}^{7} \sum_{j}^{9} x_{i j}^{r s}(\mu)+c h_{i}^{r}(\mu) \\
& \quad+c g_{i}^{r}(\mu)+c I_{i}^{r}(\mu)+e_{i}^{r}(\mu)
\end{aligned}
$$

輸送サービス：( $\mathrm{r}=1, \cdots, 7)$

$$
\begin{aligned}
& X_{7}^{r}(\mu)=\sum_{j}^{9} \sum_{s}^{7} x_{7 j}^{r s}(\mu)+c h_{7}^{r}(\mu)+c g_{7}^{r}(\mu) \\
& \quad+c I_{7}^{r}(\mu)+e_{7}^{r}(\mu)-m_{7}^{r}(\mu) \\
& =\sum_{i, j}^{9} \sum_{s}^{7} x_{i j}^{r s}(\mu) d^{r s} \theta_{i}^{r}+\sum_{i}^{9}\left(c h_{i}^{r}(\mu) d^{r h}\right. \\
& +c g_{i}^{r}(\mu) d^{r g}+c I_{i}^{r}(\mu) d^{r l}+e_{i}^{r}(\mu) d^{r 8} \\
& \left.-m_{i}^{r}(\mu) d^{8 r}\right) \theta_{i}^{r} \quad(\mathrm{i} \neq 7)
\end{aligned}
$$

\section{（2）生産要素市場}

労働市場 : $\overline{L S}=\sum_{r}^{7} \sum_{j}^{9} L_{j}^{s}(\mu)$

資本市場： $\overline{K S}^{s}=\sum_{j}^{9} K_{j}^{s}(\mu) \quad(\mathrm{s}=1, \cdots, 7)$

\begin{tabular}{|c|c|}
\hline ケース & ケースの内容 \\
\hline 基本ケース & 基準年次の実績値 \\
\hline ケース 1 & 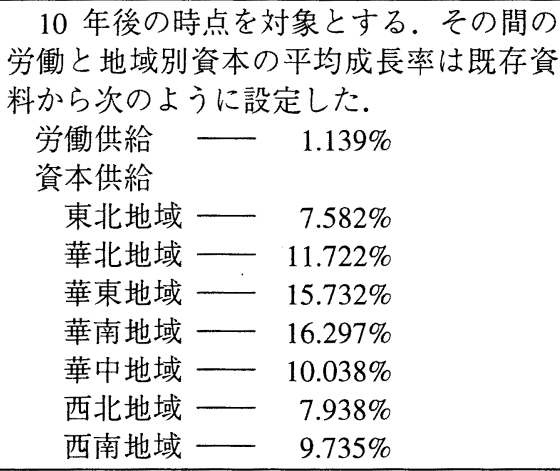 \\
\hline ケース 2 & $\begin{array}{l}\text { 労働と資本の成長はケース } 1 \text { と同じす } \\
\text { るが, 鉄道基盤整備の遅れによって, 以下 } \\
\text { の } 8 \text { ○の区間に一次エネルギー輸送 (片方 } \\
\text { 向) に制約を付ける. } \\
\text { 東北地域 } \rightarrow \text { 華東, 西南地域 } \\
\text { 華北地域 } \rightarrow \text { 華東, 西南地域 } \\
\text { 華中地域 } \rightarrow \text { 華東, 西南地域 } \\
\text { 西北地域 } \rightarrow \text { 華東, 西南地域 }\end{array}$ \\
\hline
\end{tabular}

\section{6. シミュレーション分析}

本研究では, 1992 年を基準年次とし, 10 年後の 2002 年に対してシミュレーション分析を試みた。 シ ミュレーションケースは一次エネルギー輸送に対す る制約がない場合とある場合との 2 ケースとした。
ケース内容は表 4 のようである。

表 4 ケースの内容

\section{（1）輸送制約}

中国では，地域間の一次エネルギー輸送はほとん ど鉄道輸送に依存している.1992 年の一次エネルギ 一輸送量は，鉄道輸送総量の約 50\%を占め，石炭の 鉄道輸送量は石炭産出量の $57.4 \%$ に達する。それら の輸送量は, 主に一次エネルギー産出地域と需要地 域を結ぶ路線に集中している，従って，本研究では 地域間一次エネルギーの需給が鉄道輸送に強く依存 することを考慮して, 主要一次エネルギー産地と一 次エネルギー大消費地域とのリンクに制約を付ける。

南北方向の京広線（北京一広州）と東西方向の京 滬線（北京一上海）は地域間の幹線路であり，エネ ルギー輸送の命脈とも言われている。ただし，1997 年京広線と平行的に，北京から香港までの京九線が 開通してから，南北輸送は緩和されたため，ケース 2 では，主に東北，西北地域から沿岸部の華東地域， 及び内陸山脈地帯の西南地域への一次エネルギー輸 送に焦点を当て，制約条件を設定した。

\section{（2）パフォーマンス関数}

鉄道輸送にとって, 輸送容量以上の貨物を輸送す る場合, 操車場での待ち時間などを考慮しなければ 
ならず，輸送時間は伸びることになる，従って，時 間で測った総輸送距離は増大する。輸送距離の延長 に伴い，式(29)，(30)により，中間投入と家計消費に おける一次エネルギー財の需要者価格も上昇し, 地 域別均衡解も変化する。

本研究では, 通常の BPR 曲線により, 次のような パフォーマンス関数を設定した.

$$
d^{r s}=-\left[\begin{array}{ll}
d_{0}^{r s} & x^{r s} \leq x_{0}^{r s} \\
d_{0}^{r s}\left[\frac{x^{r s}}{x_{0}^{r s}}\right]^{\gamma} & x^{r s}>x_{0}^{r s}
\end{array}\right.
$$

ここで, $x_{0}^{r s}$ : 地域 $\mathrm{r}, \mathrm{s}$ 間の輸送容量

$x^{r s}$ : 地域 $\mathrm{r}, \mathrm{s}$ 間の輸送量

$d_{0}^{r s}$ : 地域 $\mathrm{r}, \mathrm{s}$ 間の距離

$d^{r s}$ : 地域 $\mathrm{r}, \mathrm{s}$ 間の換算距離

$\gamma:$ パラメータ

本研究では, 基準ケースの地域間一次エネルギー 実績供給量を輸送容量 $x_{0}^{r s}$ とする。ここで制約をつ けた 8 区間の平均走行距離は $1924.13 \mathrm{k} \mathrm{m}$ であり, 輸 送容量以下の時, 一次エネルギーの平均貨物輸送時 間は, 出発·到着駅での列車編成・荷さばき時間, 列車走行時間, 途中駅での待ち時間を含めて, 9.76 日の 234.24 時間とされている.

しかし, 近年では, 一次エネルギーの輸送容量を 上回り, 通常は輸送容量を 2 割程度の超過で出荷し ている. 途中待ち時間の増加により, 貨物の平均輸 送時間は 17〜20日に増加し, 正常輸送時間の約 1.8 倍になっている。

それ以上に輸送される場合もしばしばあるが，車 両不足, 操車場の編車能力, 列車の途中再編などか ら貨物輸送時間はかなり伸びる．実際の輸送量が輸 送容量の 1.5 倍に達した場合, 各路線の貨物平均輸 送時間は 35 日程度となり, 輸送容量以下の時の 3.66 倍となる。これより, パラメータ $\gamma$ は 3.2 と推計さ $れ^{8)}$, パフォーマンス関数は図 2 のようになる.

\section{（3）シミュレーションの結果}

シミュレーションの結果については, 全国及び 各地域の集計指標から説明する.ケース 1 とケース
2 の厚生水準の違いは，等価的偏差 $\mathrm{EV}$ によって評 価する。ただし，ここでの EVはケース1での相対 価格体系によって算出している.

表 5 制約区間とパラメータ

\begin{tabular}{|c|c|c|}
\hline \multirow{4}{*}{$\begin{array}{l}\text { 制約する } \\
\text { 区 間 }\end{array}$} & 東北 $\rightarrow$ 華東, 西南 & $d^{13}, d^{17}$ \\
\hline & 華北 $\rightarrow$ 華東, 西南 & $d^{23}, d^{27}$ \\
\hline & 華中 $\rightarrow$ 華東, 西南 & $d^{53}, d^{57}$ \\
\hline & 西北 $\rightarrow$ 華東, 西南 & $d^{63}, d^{67}$ \\
\hline \multicolumn{2}{|c|}{ パラメータ $\gamma$} & 3.2 \\
\hline
\end{tabular}

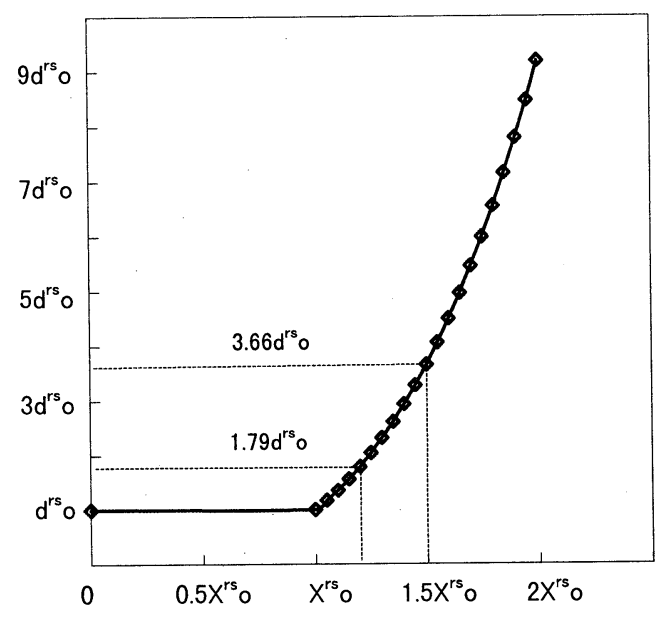

図 2 パフォーマンス関数 $(\gamma=3.2)$

\section{（a）主要経済指標のシミュレーション結果}

表 6 主要経済指標指標 (名目百万元)

\begin{tabular}{|c|c|c|c|}
\hline 指標 & 基本ケース & ケース 1 & ケース 2 \\
\hline \multirow{3}{*}{$\begin{array}{r}\text { 家計：所得 } \\
\text { 消費 } \\
\text { 貯蓄 }\end{array}$} & $1,721,949$ & $1,862,155$ & $1,858,372$ \\
\hline & $1,370,391$ & $1,486,177$ & $1,482,885$ \\
\hline & 49,318 & 53,485 & 53,366 \\
\hline \multirow{5}{*}{$\begin{array}{r}\text { 政府：収入 } \\
\text { 直接税 } \\
\text { 純間接税 } \\
\text { 支出 } \\
\text { 貯蓄 }\end{array}$} & 619,596 & 686,733 & 684,260 \\
\hline & 302,239 & 322,493 & 322,119 \\
\hline & 317,357 & 364,240 & 362,139 \\
\hline & 223,339 & 247,539 & 246,647 \\
\hline & $-203,893$ & $-225,986$ & $-225,172$ \\
\hline $\begin{array}{l}\text { 政府から家 } \\
\text { 計への移転 }\end{array}$ & 600,150 & 665,180 & 662,784 \\
\hline 投資総額 & $1,035,314$ & $1,052,132$ & $1,048,444$ \\
\hline 労働供給 & 350,137 & 386,769 & 386,769 \\
\hline 資本供給 & $1,986,906$ & $6,249,852$ & $6,249,852$ \\
\hline 賃金率 & 1.0 & 1.0 & 1.0 \\
\hline E V & - & - & 10,396 \\
\hline
\end{tabular}

注：労働と資本需要は百万元のサービスを生み出す 量を 1 単位としている. 
表 6 で示されるように, 労働と資本の成長が同じ であるにもかかわらず，ケース 2 ではケース 1 に比 ベ, 全国生産水準は低下し, EV は 103.96 億元のマ イナスである. 現在の国家財政の赤字は 460 億元で あるが，ケース 1 の相対価格体系では 163.35 億元と 計算される。したがって，ケース 2 での厚生損失は その 6 割強であり, 絶対額としてはかなりの厚生損 失と言える.

\section{(b) 地域間の集計值}

図 3 と図 4 で示されているように, 資本と労働の 成長により，基準ケースと比べて地域間経済成長の 格差が一段と拡大されている. 沿岸部の成長に伴い, 東北，華北，華中地域の一次エネルギー生産はかな り引き上げられている，供給不足のため，資源の貧 しい華東，西南地域も一次エネルギー生産の潜在力 が掘り起こされていることがわかる.

ケース 2 では, 各地域の産出量に影響が見られる. 東北と華東地域の労働需要変化に見られるように, 地域間の労働人口移動にかなり大きな変化があるこ とは注目される.本研究では, 賃金率を 1 に固定し, シミュレーションを行ったので，地域間の資本収益 率は図 6 のようである.一次エネルギー制約により， 華東地域での総産出は減少し, 資本生産性が下がる ため, 資本収益率が下がる。そして労働需要も減少 している。ここでの余剩労働力は，資本収益率の高 まりから，相対的に賃金低下となる東北，西北地域 での労働需要に吸収される形で，これらの地域に移 動している.

\section{（c）東北地域，華東地域の生産と需要}

基盤工業を主体とする東北地域における経済成長 の特徵及び一次エネルギー輸送制約から受けている 影響は, 図 7 から図 9 で表わされる.

先発地域の代表と言われている華東地域における 経済成長の特徵及びエネルギー不足による波及効果 は，図10から図 12 のようである。

東北地域では，輸送制約のため，ケース 2 ではケ 一ス 1 に比ベ,一次エネルギー生産が $2.7 \%$ 減少し, またそれと逆に，運輸部門の拡大から二次エネルギ 一産業は $2.0 \% の$ 増加となった. 運輸部門は換算距離 の増加によって, 輸送サービス量が引き上げられ,
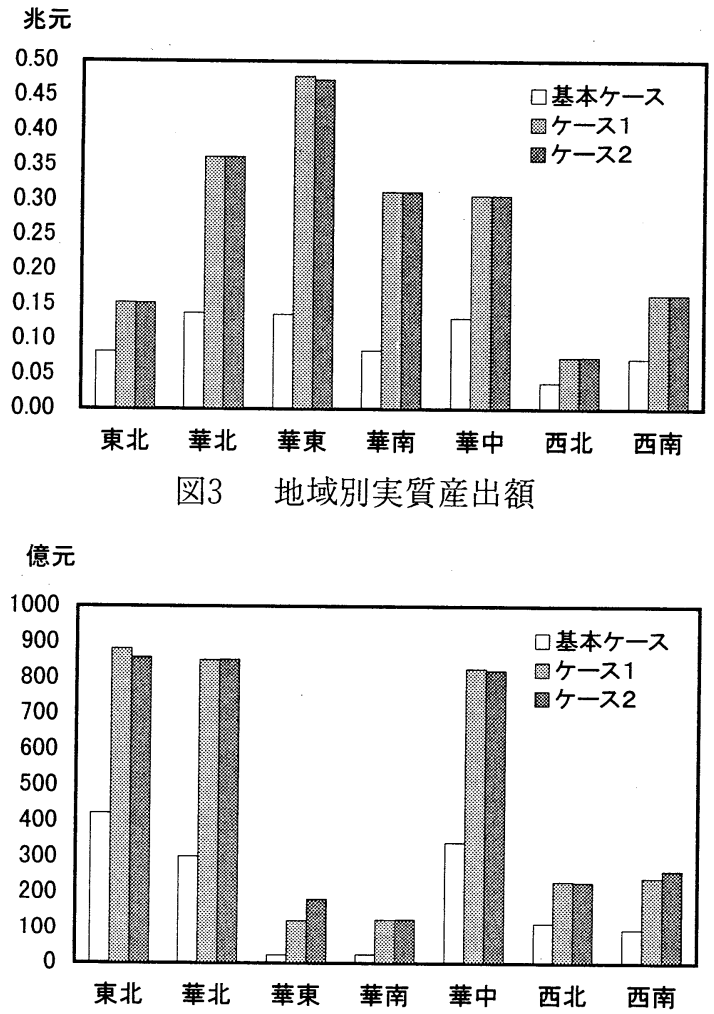

図4 地域別一次エネルギー実質産出額

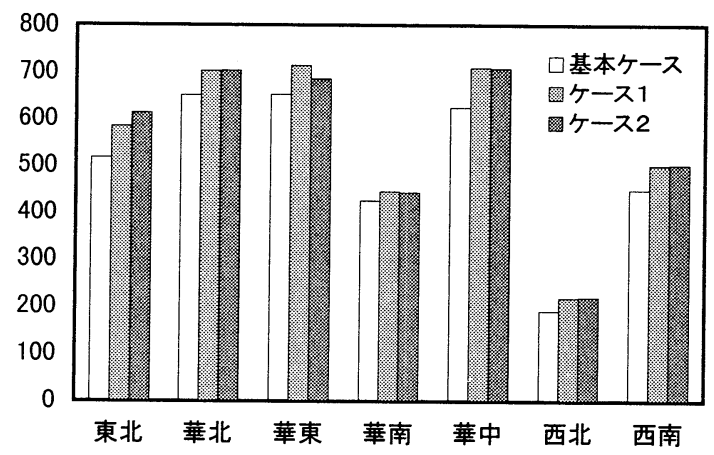

図5地域別労働需要

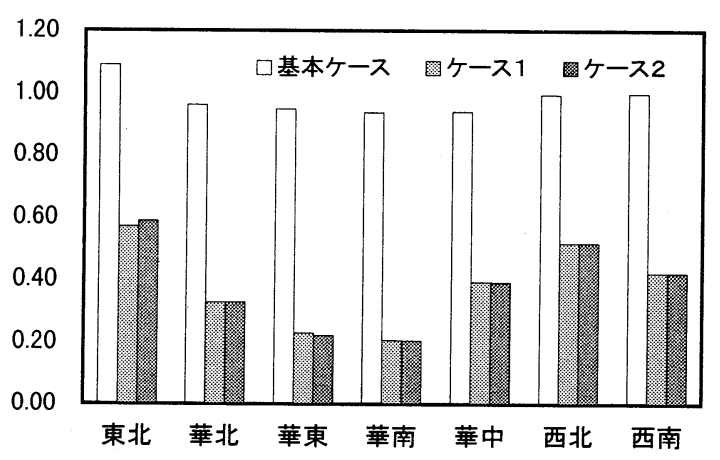




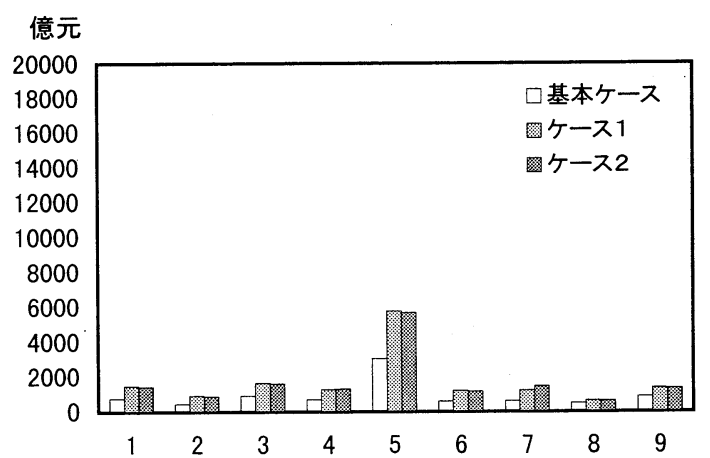

図7東北地域産業別実質産出額

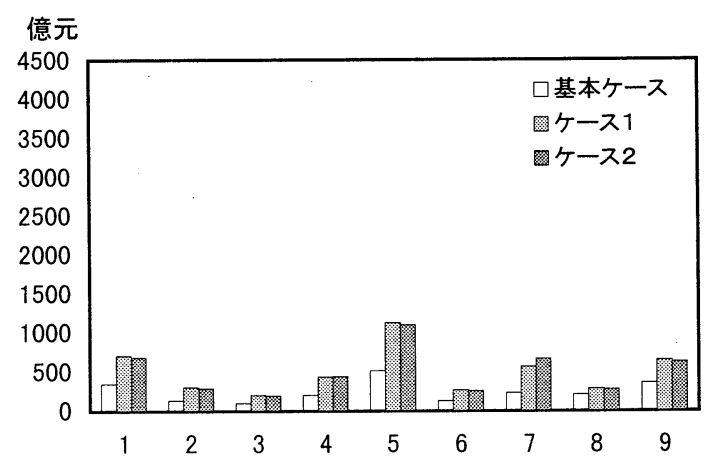

図 8 東北地域産業別実質資本需要

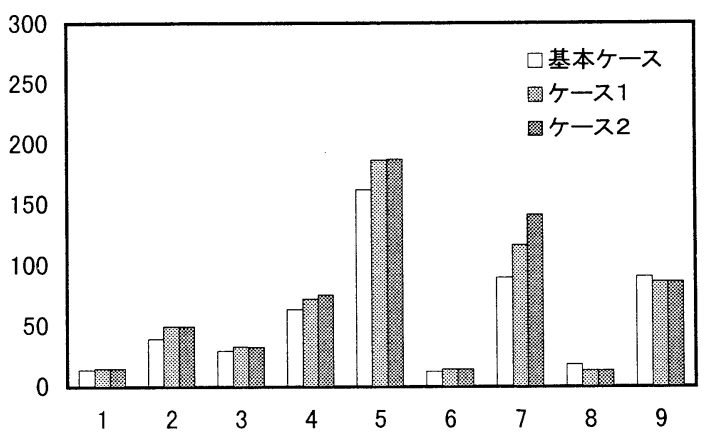

図 9 東北地域産業労働需要

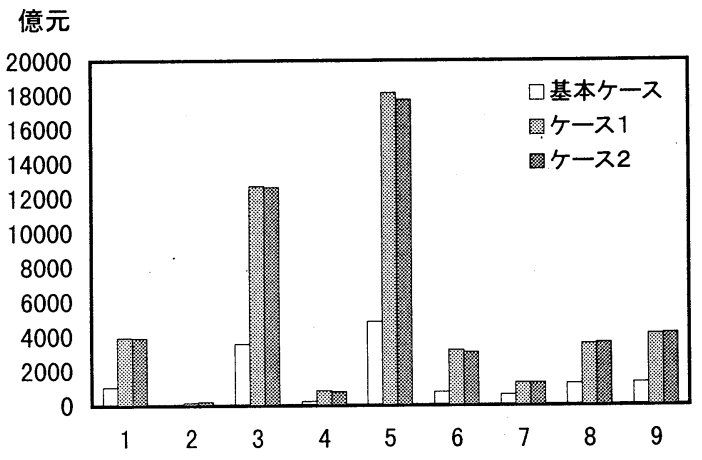

図10華東地域産業別実質産出額

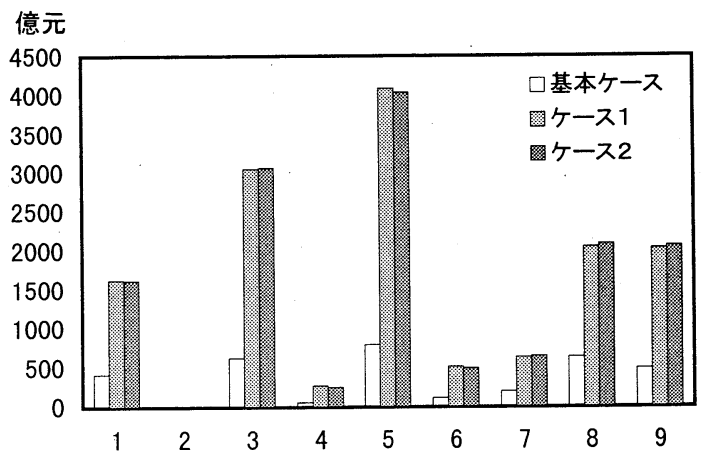

図11 華東地域産業別実質資本需要

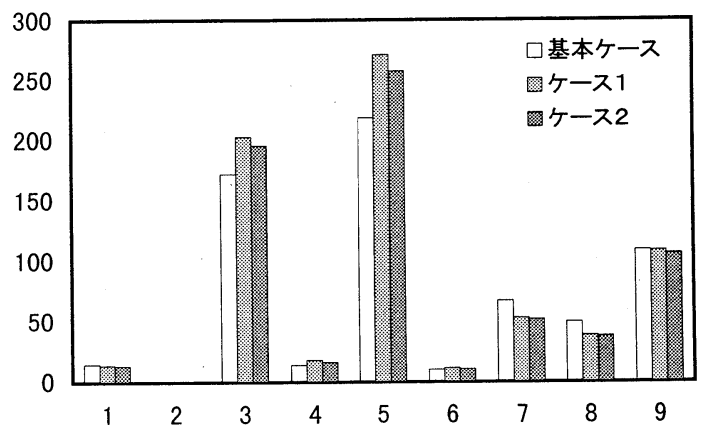

図12、華東地域産業別労働需要

18.4\%ほど実質産出額が上昇し, 地域内の資本も労働 も運輸部門へとシフトしている.

華東地域では, 一次エネルギー供給不足のため, ケース 1 と比べて地域内の一次エネルギー生産は, 49.3\%急激な上昇となるが，基準量が少ないため， 地域内需要をまかなうには全くの不十分である。こ のため, 二次エネルギーや加工製造工業の生産が減 少し, 総産出量も減少する結果となった。

\section{7.おわりに}

本研究では, 中国に関する多地域一般均衡モデル を構築し，地域間のエネルギー需給に着目して，輸 送混雑不経済を考慮したシミュレーション分析を試 みたものである。本研究のモデルは同一種類の財の 地域間代替を可能とし，また一次エネルギー輸送の 制約も限られたO Dペアのみに適用しているが，そ れでも全く制約の場合に比へ，いくつかの地域では 人きな産業構造变化が起こることや,かなりの厚生 
損失が発生することが明らかとなった。

将来の輸送制的はより厳しくなるものと想定され, 中国での長距離輸送システムの遅れは堅調な経済成 長を大きく阻害してしまうことが示唆される.

なお, 本研究の遂行にあたっては, 東北大学の安 藤朝夫先生から貴重な御指導とデー夕の提供をいた だきました。ここに感謝の意を表します。

\section{参考文献}

1) Miyata.Y. : A General Equilibrium Analysis of The Waste-Economic System - A CGE Modeling Approach - , Infrastructure Planning Review, No.12, pp.259-270, 1995.

2) Ando, A. and Shibata, T. : Estimating Interregional Trade in China for Transport Project Evaluation on the
Regional I-O Framework and Railroad Network Capacities, Selected Proceedings of the 6th WCTR, Vol.3, pp.2311-2322, 1992.

3）宮城俊彦，本部賢一：応用一般均衡分析を基礎に した地域間交易モデルに関する研究，土木学会論文 集, No.530/IV-30, pp.31-40, 1996.

4) 中国国家統計局編：1992 年度中国投入産出表 (産 業連関表），中国統計出版社，1996.

5）市村真一・王慧炣: 中国地域間産業連関表の作成, mimeo, 1993.

6) 中国国家統計局編：1985-1996 年中国統計年鑑, 中国統計出版社, 1986-1997.

7) 中国鉄道工業省編:1992-1994 年鉄道工業統計年 鑑，鉄道工業出版社，1993-1995.

8）鉄道工業省編：全国鉄路統計資料匯編，中国鉄道 工業省, 1995.

\section{中国エネルギー需給に関する多地域一般均衡分析}

\section{宫田 培 渋澤 博幸 陳 自力}

広大な国土面積を持つ中国にとり，地域間のエネルギー需給問題はエネルギー総需給のバラン スを検討することよりも，より現実的な課題と言える.中国エネルギー資源が西北内陸地域に偏 在するため, 東南沿岸地域のエネルギー需給は強く長距離輸送に依存している。この中国固有の 国土条件を考慮して, 本研究では中国大陸を 7 地域に区分した多地域一般均衡モデルを構築し, さらに輸送における外部不経済性を考慮して, 地域間エネルギー需給及び地域経済へ及ぼす影響 に関する多地域多部門の実証分析を試みた。

\section{An Interregional General Equilibrium Analysis of Energy Demand/Supply in China Yuzuru MIYATA, Hiroyuki SHIBUSATA, and Zili CHEN}

Since China has the extremely wide land area, study of equilibriating the interregional energy demand/supply is a more practical subject than that of national total energy demand/supply. However, the natural energy resources are located mainly in the undeveloped northwestern inland area, therefore, the energy demand/supply in the southeastern coastal area strongly depends on the long distance transportation. In the present study, an interregional general equilibrium model has been constructed for China's energy issues, and then the growth of energy demand/supply has been calibrated by region and by sector. Moreover restriction on the capacity of long distance transportation is examined calibrating the its effects on the interregional and intersectoral linkages. 